\title{
Growth Factors Protect PC12 Cells against Ischemia by a Mechanism That Is Independent of PKA, PKC, and Protein Synthesis
}

\author{
Irene R. Boniece' and John A. Wagner ${ }^{1,2}$ \\ 'Department of Neurology and Neuroscience and ${ }^{2}$ Department of Cell Biology and Anatomy, Cornell University Medical \\ College, New York, New York 10021
}

\begin{abstract}
We have established an in vitro model of ischemia incorporating the combination of anoxia with glucose deprivation, which is toxic to PC12 cells. In this model, nerve growth factor (NGF), basic fibroblast growth factor (bFGF), and epidermal growth factor (EGF) improve PC12 cell survival. K252a, a specific inhibitor of NGF-induced trk p140 autophosphorylation, did not alter the neuroprotection provided by EGF or bFGF, yet it completely abolished the protection provided by NGF. Activation of protein kinase A (PKA) with dibutyrylCAMP also protected during ischemia, although it was not additive with the effect provided by growth factors. Furthermore, growth factors protected a PKA-deficient mutant as effectively as the parental cell line; thus, activation of PKA is protective against ischemia but is not necessary for the action of peptide growth factors. Neither the stimulation of protein kinase $\mathbf{C}$ (PKC) with acute phorbol ester treatment nor the downregulation of PKC with chronic high-dose phorbol ester treatment resulted in an altered response to growth factors in either the PC12 wild type or PKA-deficient mutant. Thus, protection by peptide growth factors depends on neither PKA nor PKC. Furthermore, downregulation of PKC alone was protective, indicating that PKC may contribute to toxicity. Interestingly, treatment with the kinase inhibitor $\mathrm{H}-7$ was neuroprotective and may have enhanced the neuroprotective effect of NGF. In contrast, staurosporine, a broadly acting kinase inhibitor, inhibited the neuroprotective effect of NGF, but not of EGF or FGF. The protective effects of the peptide growth factors did not depend upon concurrent protein synthesis, as the inhibition of protein synthesis by anisomycin did not significantly reduce the protective effects of EGF, bFGF, or NGF. Although their precise biochemical nature has yet to be identified, the signal transduction pathways that are regulated by peptide growth factors to protect cells against ischemia are potentially important therapeutic targets.
\end{abstract}

[Key words: NGF, basic fibroblast growth factor, epidermal growth factor, kinase inhibitors, anisomycin]

\footnotetext{
Received Dec. 4, 1992; revised Feb. 22, 1993; accepted Apr. 7, 1993.

We acknowledge the support of EYO6454 and CA 40929 (J.A.W.) and T32 NS07141-13 (I.R.B.). We appreciate the advice of Dr. Carol Mattes, Dr. Mitsutoshi Endoh, and Dr. Ken Maiese. Special thanks to Mary Boniece for her grammatical expertise.

Correspondence should be addressed to John A. Wagner, Ph.D., Professor, Department of Neurology and Neuroscience, Department of Cell Biology and Anatomy, Cornell University Medical College, 1300 York Avenue, New York NY 10021.

Copyright (c) 1993 Society for Neuroscience $0270-6474 / 93 / 134220-09 \$ 05.00 / 0$
}

Ischemia can be caused by a decrease in tissue perfusion that results in an inadequate supply of oxygen, glucose, and other metabolites. Prolonged ischemia can result in the death of neurons and other cells. The mechanisms leading to cell death are not fully understood, although a number of important aspects of the process have been studied (Rehncrona et al., 1981; Auer and Siesjo, 1988; Kirschenbaum and Pulsinelli, 1990). For example, brain ischemia results in an increase in the release of the excitatory neurotransmitter glutamate, which has been shown to be a mediator of neuronal cell death (Rehncrona et al., 1981; Benveniste et al., 1984; Rothman and Olney, 1986; Goldberg et al., 1987; Westerberg et al., 1989; Choi, 1990). Postsynaptic binding of glutamate to its receptor results in a complex signaling cascade that includes an increase in intracellular calcium (MacDermott et al., 1986; Mayer et al., 1987) and enhanced degradation of phospholipids with the formation of the protein kinase $\mathrm{C}(\mathrm{PKC})$ activators diacylglycerol (DAG) and arachidonic acid (for a review, see Bockaert et al., 1990). While it is postulated that PKC and calcium/calmodulin-dependent kinase may play a role in neuronal cell death, the precise cascade of events that lead to cell death during ischemia is not known (reviewed in Saitoh et al., 1991).

Peptide growth factors provide trophic support for both PNS and CNS neurons (Morrison et al., 1988b; Stemple et al., 1988; Walicke, 1988; Ernsberger et al., 1989; Cattaneo and McKay, 1991; Gage et al., 1991). In addition, they have been shown to promote neuronal cell survival in in vitro and in vivo models of neuronal injury (Otto et al., 1987; Lipton et al., 1988; Otto and Unsicker, 1990; Faktorovich et al., 1992) and neural injury causes changes in the expression of some peptide growth factors (Finklestein et al., 1988, 1990a,b; M. Endoh and J. A. Wagner, unpublished observation; Logan et al., 1992). NGF is a targetderived polypeptide growth factor that provides necessary trophic support for sensory and sympathetic neurons of the PNS (Bottenstein et al., 1980; Thoenen and Barde, 1980). In the CNS, NGF is located in highest concentration in the hippocampus, where it exerts a trophic effect on cholinergic neurons projecting there from the basal forebrain (Korsching et al., 1985; Johnston et al., 1987). Administration of NGF into the rat brain results in an increase in ChAT levels in the hippocampus, septum, and striatum (Gnahn et al., 1983; Hefti et al., 1984; Mobley et al., 1985). In addition, intraventricular injection of NGF in the rat after fimbria-fornix transection has been shown to protect against the loss of cholinergic neurons in the septum and diagonal band (Hefti, 1986; Williams et al., 1986; Kromer, 1987).

Other peptide growth factors share some of the characteristics of NGF. Like NGF, basic fibroblast growth factor (bFGF) pro- 
motes survival of axotomized cholinergic neurons of the basal forebrain after fimbria-fornix transection (Anderson et al., 1988). bFGF promotes the survival of severed optic axons (Sievers et al., 1987) and provides trophic support for primary cultures of CNS neurons. bFGF expression has been shown to be increased after stroke and is thought to play a role in wound healing and functional recovery (Baird and Walicke, 1989; Finklestein et al., 1990b; M. Endoh, personal communication). Epidermal growth factor (EGF) elicits many of the responses common to NGF and bFGF in $\mathrm{PC} 12$, including stimulating protein phosphorylation, activating second messenger systems and specific enzymes, and inducing immediate-early genes (Greenberg et al., 1985; Heasley and Johnson, 1989; Chao, 1992). In PC12, however, EGF is not a differentiating factor but a mitogenic factor (Huff ct al., 1981). In other ccll populations, EGF has a ncuroprotective effect. EGF protects primary hippocampal cultures from glutamate toxicity (Pauwels et al., 1989) and anoxia (Maiese et al., in press), and it also protects cortical cultures from anoxia (Kinoshita et al., 1990). How peptide growth factors exert their survival-promoting effect is not yet known. Determining the signal transduction pathways involved in their effect is of obvious clinical interest, as peptide growth factors have been implicated in the process of brain development, neuronal plasticity, and repair.

The rat pheochromocytoma cell line PC12 (Greene and Tischler, 1976), which displays phenotypic traits associated with both adrenal chromaffin cells and sympathetic neurons, is a useful model system for exploring signal transduction pathways. Upon treatment with NGF or FGF, PCl2 cells develop features of sympathetic neurons; that is, they stop dividing, develop processes, and demonstrate increased electrical excitability and increased levels of ChAT (Dichter et al., 1977; Greene and Tischler, 1982). In addition to stimulating differentiation, NGF or bFGF promotes survival of PC1 2 cells in serum-free medium, and the activation of intracellular protein kinases plays a key role in this process (Greene, 1978; Rukenstein et al., 1991). NGF has been shown to activate several protein kinases, including its cell surface receptor (Klein et al., 1991; Meakin and Shooter, 1991), N-kinase (Volonte et al., 1989), the S6 kinases (Blenis and Erikson, 1986; Hashimoto and Hagino, 1990), a proline-directed kinase (Vulliet et al., 1989), MAP2/ERK kinases (Miyasaka et al., 1990; Boulton et al., 1991), and PKC (Hama et al., 1986; Heasley and Johnson, 1989). Activators of protein kinase A (PKA, i.e., the cAMP-dependent protein kinase) have been shown to mimic some of NGF's effects, including protection against serum deprivation. While PKA is not essential for many of NGF's kcy cffccts, it has been implicated in the NGF-induced activation of tyrosine hydroxylase (Cremins et al., 1986), the induction of voltage-dependent sodium channels (Kalman et al., 1990; Ginty et al., 1992), and the downregulation of calmodulin-dependent kinase activity (Brady et al., 1990). bFGF stimulates the differentiation of PC12 cells in a way that is reminiscent of NGF by activating a cell surface protein tyrosine kinase as well as a cascade of intracellular protein kinases (reviewed in Schlessinger and Ullrich, 1992). Because of the well-characterized signaling pathways in $\mathrm{PC1}$, we elected to use this line as well as a PKA-deficient PC1 2 mutant to examine the effects of ischemia, the potential neuroprotective effect of peptide growth factors, and the role of second messenger systems in mediating cell death and cell survival. If the activation of defined second messenger systems modulates cell death during ischemia, then a careful study of these signaling pathways will increase our understanding of the cascade of events that leads to cell death.

\section{Materials and Methods}

Cell culture. Wild-type PC1 2 cells and the PKA-deficient PC1 2 mutant AB11.0 (Ginty et al., 1991) were maintained in culture in Dulbecco's modified Eagle's medium (DMEM) supplemented with $5 \%(\mathrm{v} / \mathrm{v})$ horse serum (HS) and $10 \%(\mathrm{v} / \mathrm{v})$ fetal bovine serum (FBS) at $37^{\circ} \mathrm{C}$ in an atmosphere of $10 \% \mathrm{CO}_{2}$ and $90 \%$ room air.

In vitro ischemia model. To study cell survival after ischemia, $\mathrm{PC} 12$ or AB 11.0 cells were plated in DMEM $/ 5 \% \mathrm{HS} / 10 \% \mathrm{FBS}$ on polylysine (Sigma)-coated 24-well Nunc plates at $2 \times 10^{5}$ cells per well and allowed to adhere overnight. To provide a glucose-free environment, the cells were washed with a glucose-free Earle's Balanced Salt Solution (EBSS) at a $\mathrm{pH}$ of 7.4 and supplemented with penicillin $(50 \mathrm{U} / \mathrm{ml})$ and streptomycin $(50 \mathrm{mg} / \mathrm{ml})$, and then placed in fresh glucose-free EBSS. To provide an anoxic environment, cells were then placed into an incubator without oxygen, containing $95 \%(\mathrm{v} / \mathrm{v})$ nitrogen and $5 \%(\mathrm{v} / \mathrm{v}) \mathrm{CO}_{2}$ at $37^{\circ} \mathrm{C}$ for a period of $8 \mathrm{hr}$. At the end of the exposure period, cells were returned to DMEM $/ 5 \%$ HS $/ 10 \%$ FBS supplemented with penicillin and streptomycin and an atmosphere of $10 \% \mathrm{CO}_{2} / 90 \%$ room air at $37^{\circ} \mathrm{C}$. Cell death was assayed using the trypan blue exclusion method $24 \mathrm{hr}$ later. Briefly, trypan blue was added to a final concentration of $0.04 \%$ and cultures were counted after a period of $20-60 \mathrm{~min}$ using a phasecontrast microscope. Cells were counted in random fields until a total of between 200 and 500 cells (viable plus nonviable) was reached. We chose to determine the extent of cell death at $24 \mathrm{hr}$ after the cells were restored to normal medium as there is a population of cells that is destined to die yet does so only after a delay.

PKC was downregulated by pretreating with $1 \mu \mathrm{M}$ phorbol myristate acetate (PMA) in $0.06 \%$ dimethyl sulfoxide (DMSO) $(\mathrm{v} / \mathrm{v}$; Sigma) for $24 \mathrm{hr}$ prior to the exposure period with continued treatment throughout the exposure and postexposure period. This procedure results in a population of cells that has less than $1 \%$ of the normal level of PKC activity and that is functionally deficient in PKC-dependent increases in transcription (Damon, 1990, \#31; additional data not shown). Kinase inhibitors H-7 (60 $\mu \mathrm{M}$; Sigma), staurosporine [10 nM in $0.002 \%$ DMSO (v/v); Sigma], and K252a [200 nM in 0.009\% DMSO (v/v); Kamiya Biomedical Co.] were added $12 \mathrm{hr}$ prior to the ischemic period and the cells were maintained in their presence throughout the ischemic and postischemic periods. Dibutyryl cyclic AMP (1 mM; Sigma) and PMA (100 nM; Sigma) were added to stimulate PKA and PKC, respectively, at the initiation of ischemia and treatment continued throughout the postischemic period. Use of vehicle controls containing an equivalent concentration of DMSO did not alter cell survival. Growth factors were added $11 \mathrm{hr}$ prior to the exposure period and cells were maintained in their presence throughout the experimental period. Human recombinant EGF $(10 \mathrm{ng} / \mathrm{ml})$ and human recombinant $\mathrm{bFGF}(10 \mathrm{ng} / \mathrm{ml})$ were obtained from R \& D Systcms; NGF (100 ng/nl) was isolated and purified from mouse submaxillary gland according to the method of Mobley et al. (1976).

Protein synthesis. To quantify protein synthesis, $\mathrm{PC} 12$ cells were plated in DMEM $/ 5 \%$ HS $/ 10 \%$ FBS on 24 -well plates and were treated with the appropriate dose of the protein synthesis inhibitor anisomycin for $2 \mathrm{hr}$, after which they were washed and replaced with leucine-free medium (ICN Flow). ${ }^{3} \mathrm{H}$-leucine $(2 \mu \mathrm{Ci} / \mathrm{ml}$; Amersham) was added in the presence or absence of anisomycin and cells were incubated for $1 \mathrm{hr}$. Nonspecific binding was tested by using a $1 \mathrm{~min}$ exposure to ${ }^{3} \mathrm{H}$-leucine prior to washing the cells. The cells were washed with PBS and detached by the addition of $750 \mu \mathrm{l}$ of $0.1 \mathrm{M} \mathrm{NaOH}$ followed by transfer to a 1.5 $\mathrm{ml}$ Eppendorf tube. Protein was precipitated by the addition of $250 \mu \mathrm{l}$ of $100 \%(\mathrm{w} / \mathrm{v})$ trichloroacetic acid (TCA) and $10 \mu \mathrm{l}$ of bovine serum albumin $(10 \mathrm{mg} / \mathrm{ml})$ at $4^{\circ} \mathrm{C}$ for $90 \mathrm{~min}$. Precipitants were collected by filtration onto Whatman glass microfiber filters, washed once with $10 \%$ TCA, twice with $5 \% \mathrm{TCA}$, and twice with $95 \% \mathrm{EtOH}$, and then allowed to dry prior to scintillation counting. Experiments testing the effect of anisomycin itself on cell viability utilized a $24 \mathrm{hr}$ exposure period to the protein synthesis inhibitor. For the effect of anisomycin on PC12 cells during ischemia, anisomycin was added $1 \mathrm{hr}$ prior to the exposure to ischemia, and growth factors were added at the time of ischemia. Cells were maintained in anisomycin in the presence and absence of growth factors throughout the exposure and postexposure periods. Determination of cell viability was performed $24 \mathrm{hr}$ later. 


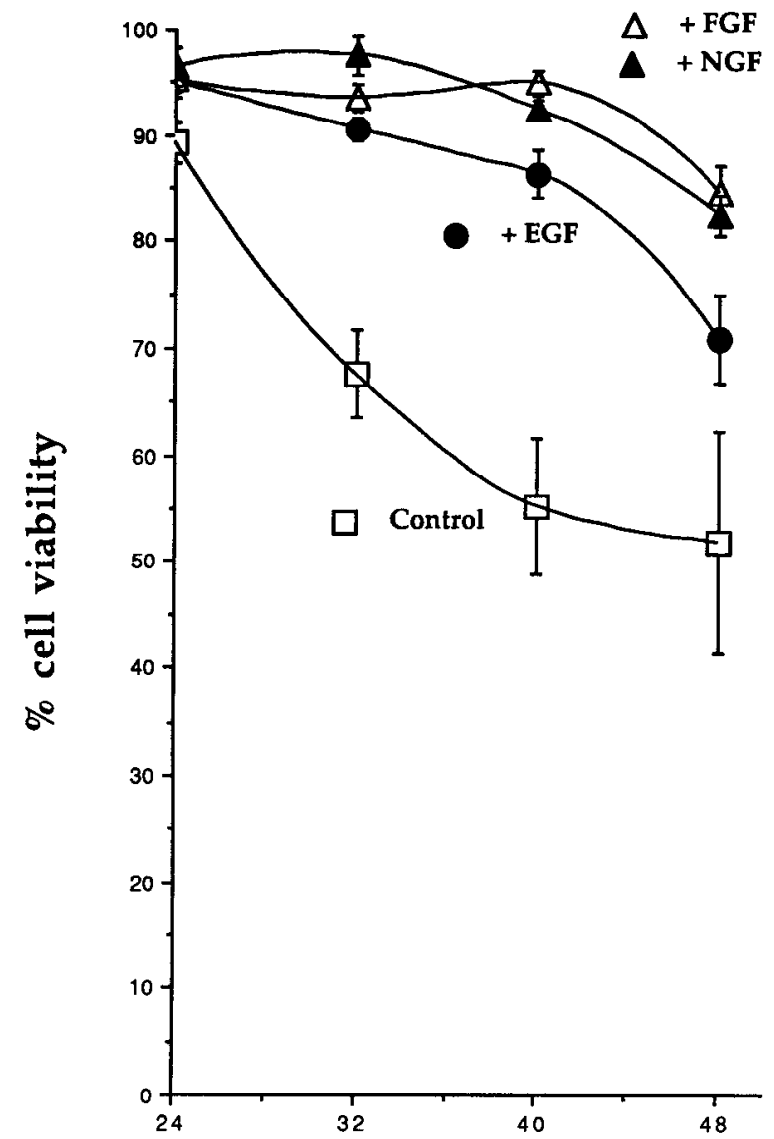

Time in balanced salt solution, hours

Figure 1. Growth factors promote survival of PC.12 cells during glucose deprivation. $\mathrm{PCl} 2$ wild-type cells were exposed to either no growth factor, EGF $(10 \mathrm{ng} / \mathrm{ml})$, bFGF $(10 \mathrm{ng} / \mathrm{ml})$, or NGF $(100 \mathrm{ng} / \mathrm{ml})$, and the normal medium was replaced with a balanced salt solution containing the same growth factor for the period indicated in the abscissa so that the cells were deprived of glucose, vitamins, amino acids, and serum. Afterward, the cells were then returned to normal medium and maintained in the presence of the same added growth factors for an additional $24 \mathrm{hr}$ before viability was determined utilizing the trypan blue exclusion method. Data represent the means \pm SEM of three trials from one of two experiments that gave equivalent results.

\section{Results}

Peptide growth factors promote PC12 cell survival during glucose deprivation. In the initial series of experiments, PC12 cells were incubated in a glucose-free EBSS for increasing periods of time. Thus, this model consisted not only of glucose deprivation but also vitamin, amino acid, and serum deprivation. Viability was assayed $24 \mathrm{hr}$ following the ischemic period. In this model cell viability was greater than $90 \%$ during the first $24 \mathrm{hr}$, but cell viability decreased dramatically in the next $24 \mathrm{hr}$ period to $50-$ $60 \%$ (Fig. 1). NGF, bFGF, and EGF all promoted cell survival at each interval in this period, although EGF was somewhat less efficacious than NGF and bFGF (Fig. 1). All the growth factors were very effective until $40 \mathrm{hr}$, after which even the growth factor-treated cultures began to lose viability (Fig. 1). As shown below (Figs. 2, 3), NGF, bFGF, and EGF were also neuroprotective when PC12 cells were exposed to $8 \mathrm{hr}$ of anoxia in a glucose-free balanced salt solution, and we decided to use an ischemic model including both hypoglycemia and anoxia to study the protective effects of peptide growth factors and second

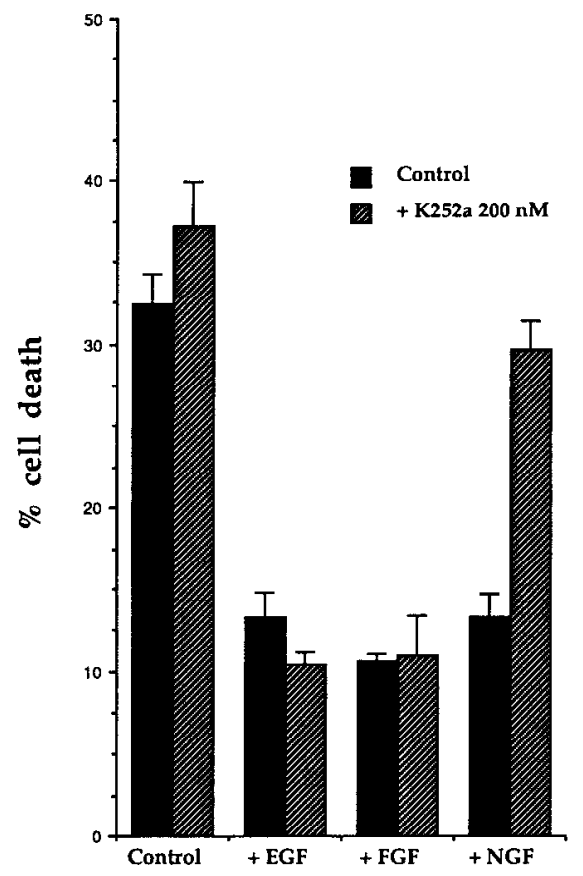

Figure 2. Growth factors improve cell survival during ischemia by more than $50 \%$, and the protective effect of NGF is abolished by $\mathrm{K} 252 \mathrm{a}$. PC1 2 cells were exposed to either EGF $(10 \mathrm{ng} / \mathrm{ml})$, bFGF $(10 \mathrm{ng} / \mathrm{ml})$, or NGF $(100 \mathrm{ng} / \mathrm{ml})$ or maintained in the absence of any exogenous growth factor in the presence or absence of K252a $(200 \mathrm{nM})$, as described in Materials and Methods, and the medium was replaced with a balanced salt solution in an oxygen-free environment. After an $8 \mathrm{hr}$ period of ischemia, cells were maintained in the presence of the same growth factors $\pm \mathrm{K} 252 \mathrm{a}$ for an additional $24 \mathrm{hr}$ in serum-containing medium supplemented with the same growth factors and then scored for viability. Data represents the means \pm SEM of a total of four trials taken from two separate experiments.

messenger systems in greater detail. Although this is a reasonable model of ischemia, it lacks many of the aspects of ischemia that occur in vivo, including acidosis, hyperkalemia, and other ionic imbalances.

Peptide growth factors are protective against the combination of oxygen and glucose deprivation, and $N G F$ 's neuroprotective effect occurs through a $\mathrm{K} 252 \mathrm{a}$-sensitive cell surface receptor. When PC1 2 cells were deprived of oxygen and glucose for a period of $8 \mathrm{hr}$, about $30 \%$ of the cells died (Fig. 2), but EGF, NGF, and bFGF all substantially increased cell survival (Fig. 2). The kinase inhibitor K252a prevents many of NGF's effects on PC12, including neuritogenesis, and this effect is probably causcd by blocking the NGF-dependent phosphorylation of its cell surface receptor (Hashimoto, 1988; Koizumi et al., 1988; Tischler et al., 1990; Berg et al., 1992; Ohmichi et al., 1992). To assess whether K252a also affects NGF's neuroprotective effect, PC12 cells were exposed to ischemic conditions (i.e., combined oxygen and glucose deprivation) in both the presence and absence of K252a (Fig. 2). K252a completely abolished NGF's neuroprotective effect (Fig. 2), and it blocked neuritogenesis in NGFtreated cells (data not shown). K252a did not alter survival in either the control population (by itself it was not toxic) or the EGF-treated or bFGF-treated populations, showing that it affected a pathway that is unique to NGF. As has been reported (Koizumi et al., 1988; Hashimoto and Hagino, 1989), K252a potentiated the neuritogenic effect of bFGF (data not shown).

The role of second messengers in cell survival. Activation of 


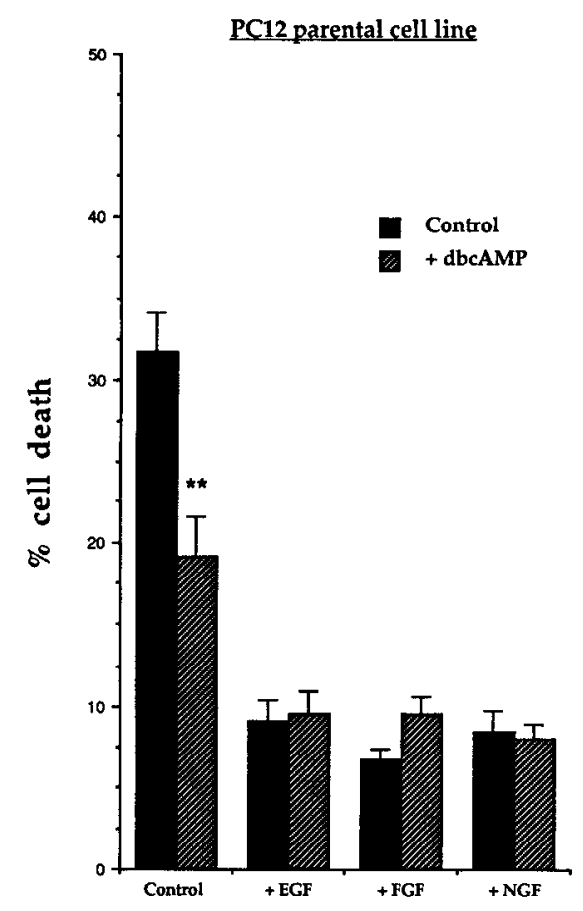

C

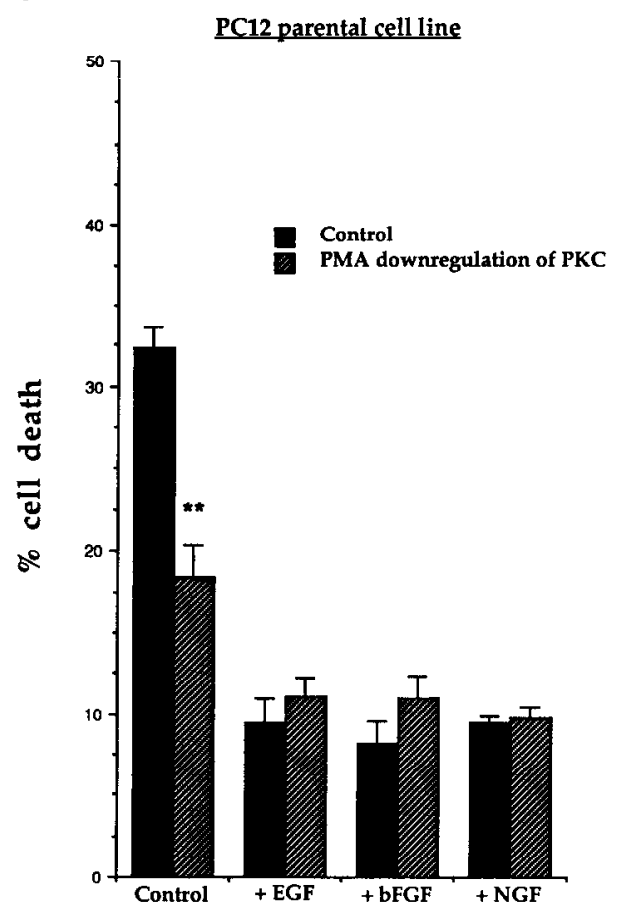

b

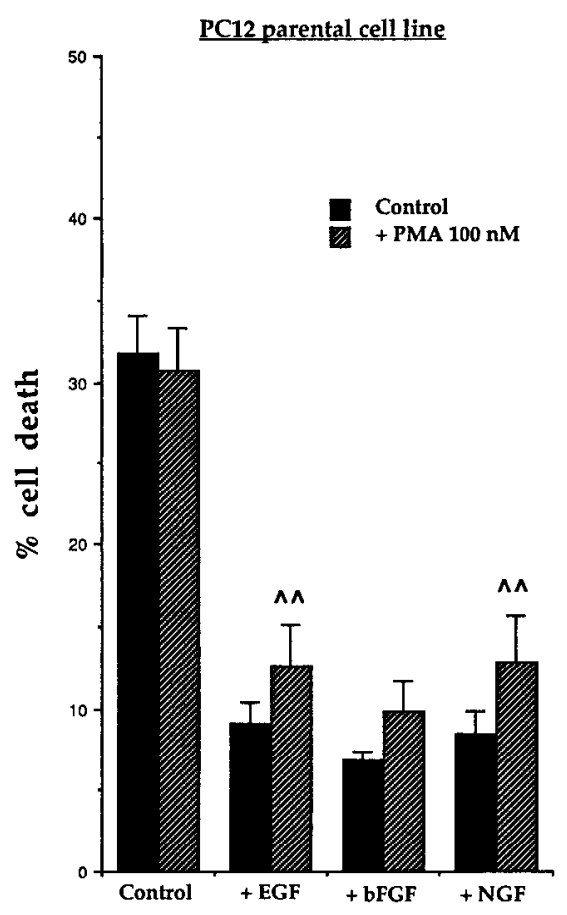

d

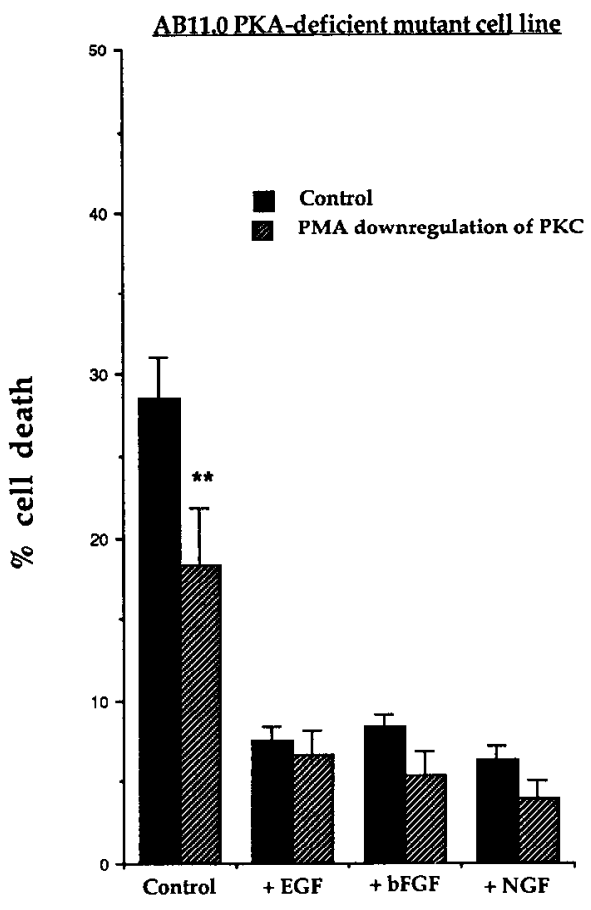

Figure 3. Neuroprotection by growth factors during ischemia is independent of PKA and PKC. $a$, Stimulation of PKA promotes survival of $\mathrm{PC} 12$ cells during ischemia without altering the response to growth factors. Cells were treated with dibutyryl-cAMP ( $d b c$ $A M P)(1 \mathrm{mM})$ in the presence or absence of EGF $(10 \mathrm{ng} / \mathrm{ml}), \mathrm{bFGF}(10 \mathrm{ng} / \mathrm{ml})$, or NGF $(100 \mathrm{ng} / \mathrm{ml})$ at the initiation of $8 \mathrm{hr}$ of ischemia. Cells were maintained in the presence of the same agents for $24 \mathrm{hr}$ postischemia, after which cell viability was assayed via trypan blue exclusion. $b$, Stimulation of PKC does not alter survival of $P C 12$ cells during ischemia or the response to peptide growth factors. PC1 2 cells were treated with 100 nM PMA in the presence or absence of growth factors at the initiation of 8 $\mathrm{hr}$ of ischemia and throughout the 24 hr postischemic period, after which cell viability was assayed. $c$ and $d$, Downregulating $\mathrm{PKC}$ with $\mathrm{PMA}$ is neuroprotective, but does not alter the survivalpromoting effect of peptide growth factors in PC12 parental cells $(c)$ or $\mathrm{AB} 11.0$ mutants $(d)$. PC12 cells $(c)$ and $\mathrm{AB} 11.0$ mutant cells $(d)$ were pretreated with 1 $\mu \mathrm{M}$ PMA for $24 \mathrm{hr}$ prior to $8 \mathrm{hr}$ of ischemia, and treatment was continued throughout the ischemic and postischemic periods. Exposure to peptide growth factors in the presence or absence of PMA began $12 \mathrm{hr}$ prior to the ischemic period and continued throughout the ischemic and postischemic periods. Data represent means \pm SEM from a total of six trials taken from two separate experiments for $a$ and $b$, a total of four trials taken from two separate experiments for $c$, and a total of five trials taken from two separate experiments for $d .{ }^{* *}, p<0.02 ; \wedge \wedge$, $p>0.10$. ANOVA followed by Tukey's test for pairwise comparisons confirmed statistical significance as indicated by ${ }^{* *}$ with $p=0.01$.
PKA can induce neuritogenesis and promote the survival of rat neonatal sympathetic and embryonic sensory neurons in culture (Rydel and Greene, 1988). To study the role of PKA in promoting cell survival during ischemia, PC12 cells were treated with the membrane-permeable analog dibutyryl-cAMP and exposed to ischemic conditions. Activation of PKA alone provided significant protection, although it was not as effective as the peptide growth factors (Fig. $3 a$ ). Activation of PKA in the presence of peptide growth factors did not provide any additional protective effect beyond that provided by EGF, bFGF, or NGF alone (Fig. 3a).

Stimulating PKC with phorbol esters decreased the survival of cortical neurons during serum deprivation, while downregulating PKC resulted in improved survival (Morrison et al., 1988a). To determine what role PKC may have in PC12 cell survival during ischemia, $\mathrm{PKC}$ was stimulated by acute treatment with the phorbol ester PMA (Fig. 3b). Stimulating PKC did not affect cell survival in the absence of exogenous growth factors, and 


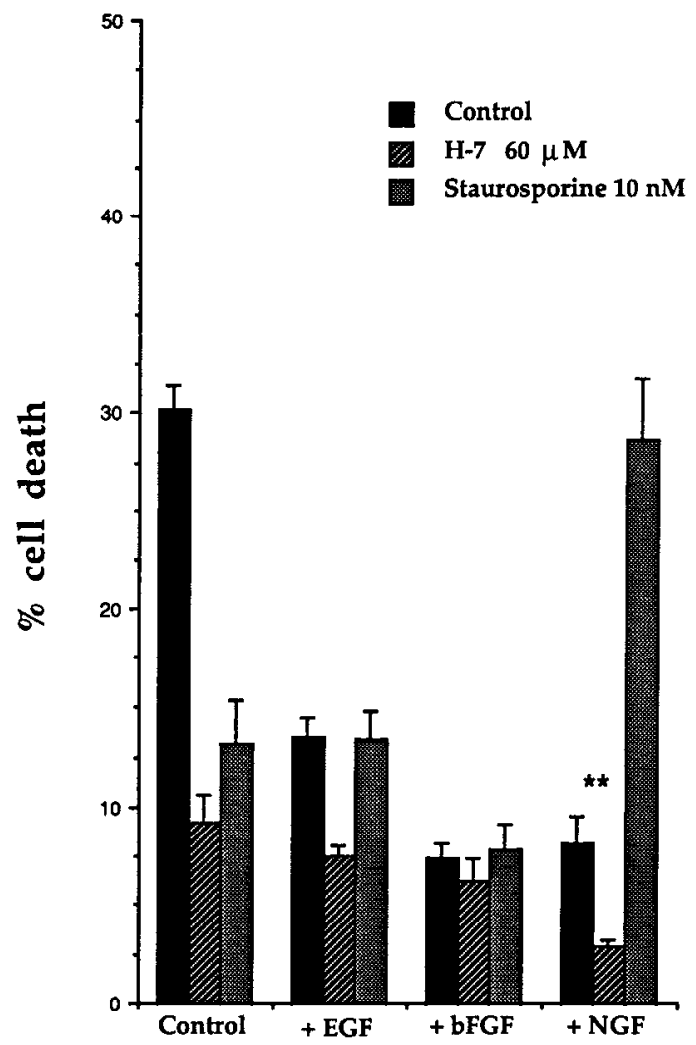

Figure 4. Kinase inhibitors $\mathrm{H}-7$ and staurosporine promote survival of $\mathrm{PCl} 2$ cells during ischemia in the absence of growth factors, but the combination of staurosporine and NGF is not neuroprotective. PC12 cells were exposed to $\mathrm{H}-7(60 \mu \mathrm{M})$ or staurosporine (10 $\mathrm{nM}) 12 \mathrm{hr}$ prior to an $8 \mathrm{hr}$ ischemic period and treatment continued through the $24 \mathrm{hr}$ postischemic period. Cells were treated with EGF $(10 \mathrm{ng} / \mathrm{ml})$, bFGF $(10 \mathrm{ng} / \mathrm{ml})$, or NGF $(100 \mathrm{ng} / \mathrm{ml})$ in the presence or absence of kinase inhibitor $11 \mathrm{hr}$ prior to ischemia (i.e., $1 \mathrm{hr}$ after addition of the kinase inhibitors) and treatment continued throughout the ischemic and postischemic periods. Cell death was assayed $24 \mathrm{hr}$ after ischemia via the trypan blue exclusion method. Data represent means \pm SEM of a total of five trials taken from two separate experiments. ANOVA followed by Tukey's test for pairwise comparisons confirmed statistical significance; ${ }^{* *}, p<0.05$ in comparing combined NGF-treated and H-7treated experiments with both NGF-treated alone and $\mathrm{H}$-7-treated alone experiments.

the small effect of PKC on the protective effects of EGF, bFGF, and NGF was not statistically significant (Fig. $3 b$ ).

Neuroprotection by peptide growth factors during ischemia is independent of $P K A$ and $P K C$. PKC is activated by EGF, bFGF, and NGF, but it is not known if this activation is necessary for the protective effects of these growth factors. To address the possible role of $\mathrm{PKC}$ in the survival-promoting effect of peptide growth factors, PKC was chronically activated and downregulated so that the effects of the growth factors could be determined in the absence of PKC. Pretreatment with $1 \mu \mathrm{M}$ PMA to downregulate $\mathrm{PKC}$ in the parental cell line resulted in a nearly $50 \%$ improvement in survival in the absence of any added growth factors (Fig. 3c), and the lack of PKC did not attenuate the ability of the growth factors to promote survival.

To determine whether PKA plays a role in the neuroprotective effects of NGF, bFGF, and EGF, we utilized a PC12 mutant cell line, $\mathrm{AB} 11.0$, which is deficient in both PKA I and II (Ginty et al., 1991). There was no difference in the percentage of cell death resulting from $8 \mathrm{hr}$ of ischemia, indicating that the lack of PKA activity did not alter survival during ischemia (Fig.

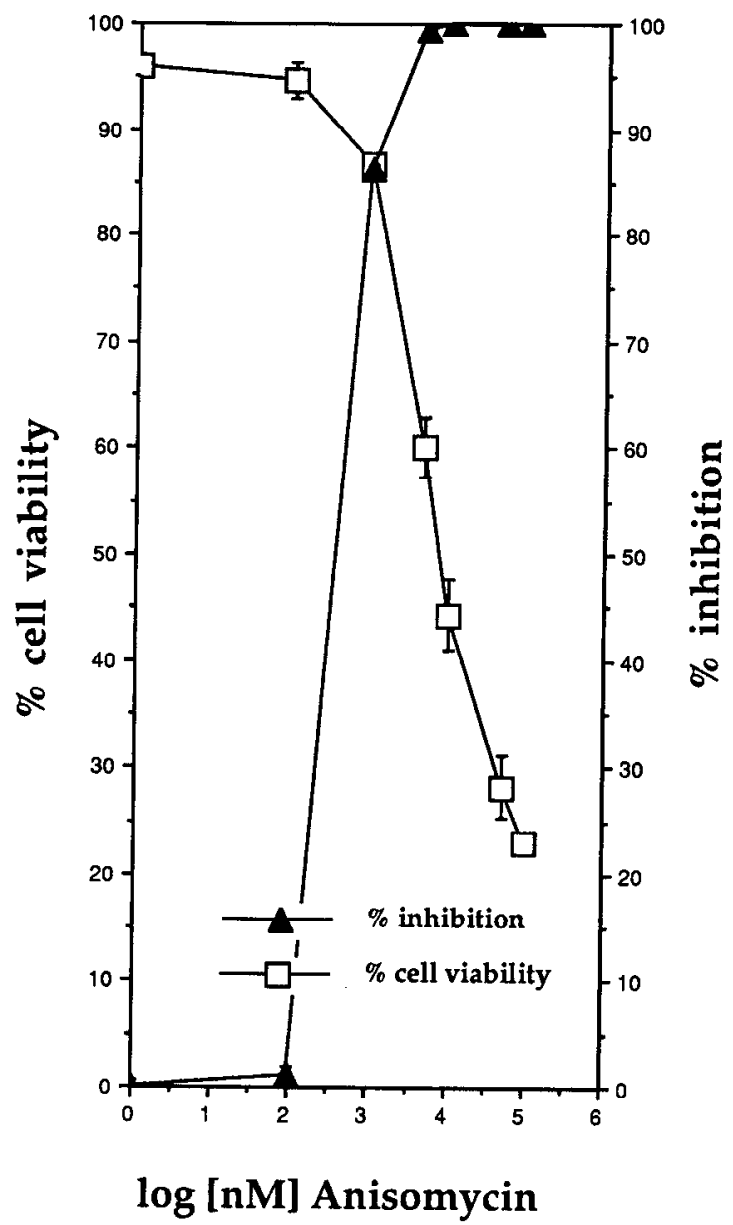

Figure 5. Effect of anisomycin on cell viability and protein synthesis. PC12 cells were treated for $24 \mathrm{hr}$ with increasing concentrations of anisomycin. The cells were then washed and incubated for an additional $24 \mathrm{hr}$ period, and viability was assayed. Data represent means \pm SEM of four experiments. To quantify protein synthesis, PC12 cells were treated with anisomycin for $2 \mathrm{hr}$ prior to labeling with ${ }^{3} \mathrm{H}$-leucine for $1 \mathrm{hr}$. Protein precipitation and quantification were performed as described in Materials and Methods. Data represent means \pm SEM of a total of six trials taken from three separate experiments.

$3 c, d)$. Likewise, the neuroprotective effects of the growth factors were equivalent between these two cell lines, proving that NGF, bFGF, and EGF promote survival independent of PKA (Fig. $3 c, d)$.

Downregulation of PKC in the PKA-deficient mutant resulted in an improved survival in the absence of addcd growth factors, while the response to growth factors was unaffected (Fig. $3 d$ ), as might be expected from experiments with wild-type cells. Taken together, these data indicate that neither kinase is necessary for EGF-, bFGF-, or NGF-induced survival in PC1 2 cells during ischemia, but the presence of activatable PKC during ischemia is detrimental.

Kinase inhibitors alter cell survival during ischemia. The kinase inhibitor $\mathrm{H}-7$, which is a competitive inhibitor of the ATP binding site of both PKA $\left(K_{i}\right.$ of $\left.3 \mu \mathrm{M}\right)$ and PKC $\left(K_{i}\right.$ of $\left.6 \mu \mathrm{M}\right)$ (Hidaka et al., 1984), augments NGF's neuritogenic affect on PC1 2 cells (Posypanova et al., 1990) and the survival-promoting effect of EGF and bFGF on serum-depleted primary rat cortical cultures (Morrison et al., 1988a). During ischemia, H-7 was as neuroprotective as the peptide growth factors in $\mathrm{PCl} 2$ (Fig. 4) and in AB11.0 cells (data not shown). There is some evidence 
for an additional enhancement of $\mathrm{H}-7$ 's neuroprotective effect in the presence of NGF, but this potential effect was not apparent with either EGF or bFGF.

Staurosporine is a more potent PKA and PKC inhibitor than H-7 (Nixon et al., 1991) and can inhibit some protein tyrosine kinases (Nakano et al., 1987). It inhibits phosphorylation of NGF's cell surface receptor, alters NGF-induced protein phosphorylations, and inhibits NGF-induced neuritogenesis (Hashimoto and Hagino, 1989; Tischler et al., 1990; Ohmichi et al., 1992). Although staurosporine did not alter the neuroprotective effects of either EGF or bFGF, it abolished the protection provided by NGF (Fig. 4). It is surprising that the combination of NGF and staurosporine is not protective. The reason for this is unclear, but it suggests that the protective effect of each agent is antagonized by the other. The neuroprotective effect of NGF apparently depends on a kinase that is sensitive to staurosporine. From our experiments, it is unlikely that this kinase is PKC, but it may be trk (Berg et al., 1992; Ohmichi et al., 1992).

Peptide growth factors do not require protein synthesis to promote survival. To determine whether the neuroprotective response to growth factors during ischemia requires protein synthesis, PC1 2 cells were treated with the protein synthesis inhibitor anisomycin. Preliminary data showed that prolonged treatment $(24 \mathrm{hr}$ ) with $100 \mu \mathrm{M}$ anisomycin is toxic to PC12 cells (see also Fig. 5). We therefore studied the effect of varying concentrations of anisomycin to determine a concentration where there was a substantial effect on protein synthesis without having a pronounced effect on cell viability (Fig. 5). At a concentration of $1 \mu \mathrm{M}$, anisomycin significantly inhibited protein synthesis $(86 \%)$ yet resulted in a minimal decrease in cell survival $(87 \%$ viable at $24 \mathrm{hr}$ ); higher doses resulted in a marked decrease in cell survival (Fig. 5). EGF, bFGF, and NGF all protected against ischemia in the presence of 0.1 and $1.0 \mu \mathrm{m}$ anisomycin (where protein synthesis was inhibited $1 \%$ and $86 \%$, respectively) while both bFGF and NGF protected at $10 \mu \mathrm{M}$ anisomycin (where protein synthesis was inhibited by more than $95 \%$; Fig. 6). Thus, the protective effects of these three growth factors are largely independent of concurrent protein synthesis.

\section{Discussion}

We have established a model of ischemia in PC12 cells and have shown that it can be used to define the signaling pathways involved in modulating cell death during ischemia. We have also shown that modulation of kinase activities can have an effect on cell viability in our model of ischemia. NGF, bFGF, and several other pharmacological agents rescue cells during serum deprivation (Rukenstein et al., 1991), while EGF supported short-term but not long-term survival. In contrast, we have found that the three peptide growth factors protect almost equivalently in our model of ischemia. Activation of PKA, but not PKC, protects against serum deprivation (Rukenstein et al., 1991) as well as in our model of ischemia. Likewise, the protective effects of growth factors are largely independent of protein synthesis in the two models, suggesting a similarity in the two models of cell death. Death of fibroblasts due to serum deprivation is also reduced by the activation of PKA in a translation-independent manner, but, in contrast to $\mathrm{PC} 12$ cells, the activation of PKC has a protective effect in this model (Tamm and Kikuchi, 1991).

We found that stimulating PKA during ischemia is indeed neuroprotective, and Rydel and Greene (1988) demonstrated that analogs of cAMP can replace NGF in promoting long-term

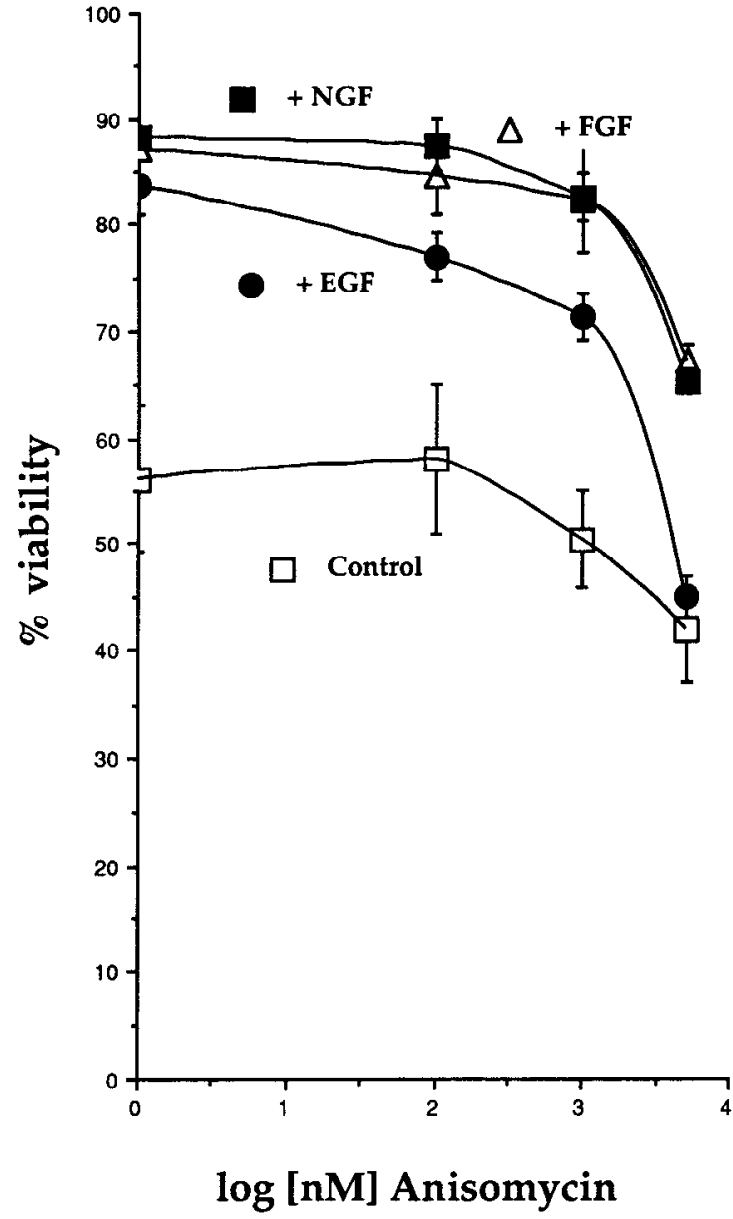

Figure 6. Peptide growth factors promote survival during ischemia in the absence of concurrent protein synthesis. PC12 cells were treated with anisomycin $(0.1 \mu \mathrm{M}, 1.0 \mu \mathrm{M}$, or $5.0 \mu \mathrm{M})$ for $1 \mathrm{hr}$ prior to ischemia, and treatment continued throughout the postischemic period. Cell viability was assayed $24 \mathrm{hr}$ after ischemia. Data represent means $\pm \mathrm{SEM}$ of three trials from one of three comparable experiments.

survival of rat neonatal sympathetic and embryonic sensory neuronal cultures, yet cells that are deficient in PKA are as sensitive to ischemia as cells that have normal levels of PKA. Furthermore, peptide growth factors are protective independent of PKA, as demonstrated by our experiments with the PKAdeficient mutant AB11.0. Thus, although PKA activation is neuroprotective, this is not the mechanism through which growth factors enhance survival. Similarly, Ruckenstcin ct al. (1991) found that NGF and bFGF continued to exert a survival-promoting effect during serum deprivation even in the absence of PKA activity.

In PC12, NGF stimulates the hydrolysis of phosphoinositides to produce DAG and arachidonic acid, known activators of PKC (Contreras and Guroff, 1987; Chan et al., 1989). NGF also induces the translocation of PKC from the cytosolic to the membrane fraction of PC12 cells (Kondratyev et al., 1990). Thus, PKC is one of the second messengers used by NGF. Nevertheless, neither the stimulation nor the downregulation of PKC altered the growth factor-induced protective effect in either $\mathrm{PC} 12$ or the PKA-deficient mutant. Although phorbol esters do not alter survival during serum starvation (Rukenstein et al., 1991), PMA has been shown to potentiate the neuritogenic effect of NGF on PCl2 (Burstein et al., 1982; Hall et al., 1988). PKC is 
induced during ischemia and may have a role in ischemic cell death. For example, PKC is translocated from the cytosolic to particulate fraction and activated following ischemia in the fetal rat brain (Louis et al., 1988). This was accompanied by an increase in a calcium phosphatidylserine-independent kinase, which is thought to be a cleavage product of PKC. Cardell et al. (1990) observed changes in the location of specific isoforms of PKC including the neuronal isoform PKC $\gamma$ after ischemia in the adult rat. The precise role PKC may have in neuronal cell death has yet to be determined.

$\mathrm{K} 252 \mathrm{a}$ and staurosporine are both selective inhibitors of the autophosphorylation of $t r k$ (Berg et al., 1992; Ohmichi et al., 1992), both inhibit the biological effects of NGF (Koizumi et al., 1988; Hashimoto and Hagino, 1989; Tischler et al., 1990; Ohmichi et al., 1992), and both inhibit the protective effects of NGF, but not EGF or bFGF. While K252a enhances FGF's neuritogenic effect (Koizumi et al., 1988; Hashimoto and Hagino, 1989; I. R. Boniece and J. A. Wagner, unpublished observation) and the bFGF- and EGF-induced activity of ornithine decarboxylase (Koizumi et al., 1988), there was no alteration of the survival-promoting effect of either bFGF or EGF. We suggest that the site of action of $\mathrm{K} 252 \mathrm{a}$ and staurosporine is probably the receptor for NGF.

H-7 was as protective as the peptide growth factors but the site of action for the protective effects of $\mathrm{H} 7$ is not clear. $\mathrm{H}-7$ is a competitive inhibitor of the ATP binding site of both PKA and PKC (Hidaka et al., 1984), and has been shown to enhance the survival-promoting effect of EGF and bFGF on serum-depleted primary rat cortical cultures (Morrison et al., 1988a), and the neuritogenic response to bFGF and NGF in PC12 (Posypanova et al., 1990). H-7 does protect against ischemia, but it seems unlikely that it is acting through PKA or PKC because of the experiments with the PKA- and PKC-deficient cells that were discussed above. Furthermore, staurosporine, which is a more potent PKA and PKC inhibitor than $\mathrm{H}-7$, did not alter the protective effects of either EGF or bFGF. Together, our data suggest that the enhancement of the survival-promoting effect of peptide growth growth factors by $\mathrm{H}-7$ occurs through an unknown mechanism.

We have demonstrated that growth factors continue to exert a protective effect during ischemia independent of protein synthesis. Similar results were obtained by Ruckenstein et al. (1991), who demonstrated that the inhibition of RNA or protein synthesis did not alter growth factor-induced survival of $\mathrm{PC} 12$ cells during serum starvation. Thus, growth factor-induced protein synthesis is apparently not a necessary element in the events that protect PC12 cells from ischemia or serum deprivation. Interestingly, the protective effect of FGF on glutamate toxicity in hippocampal neurons requires transcriptional activity (Mattson et al., 1989), supporting the idea that different aspects of the signaling mechanism used by growth factors may be required to confer protection under different conditions. It is necessary to consider, however, that PC12 cells mav be limited in terms of the importance of conclusions drawn, as this is an immortalized cell line and may respond atypically.

Our experimental model, which deprives cells of energy derived from both oxidative phosphorylation and glycolysis, differs from the serum deprivation model used by Ruckenstein et al. (1991), which presumably leads to cell death because of a deficiency of growth factors. It is complementary to demonstrate, however, that cell survival within these two different models appears to be affected similarly by growth factors and intracellular signal transduction pathways. Indeed, the commonality of our findings with those of Ruckenstein et al. suggests that growth factors may provide a generalized neuroprotective effect to a variety of metabolic insults through similar mechanisms.

Inhibitors of RNA and protein sythesis have been shown to block apoptosis in certain cases (Cohen and Duke, 1984; Shi et al., 1989), leading to the concept of "death genes" whose expression may be regulated by growth factors. Since continued protein synthesis plays a less significant role during ischemiainduced cell death and in the protective effects of the growth factors, it is likely that apoptosis and ischemic cell death in this model system are fundamentally different processes. We conclude that several kinases play a role in mediating the toxic cffccts of ischemia and that modification of these kinase activities by growth factors is likely to be an important component of their protective effects. Likewise, pharmacological agents that modify kinase activity may be of use therapeutically; therefore, the identification of the specific kinases that are important is a key step in the development of clinically useful agents.

\section{References}

Anderson KJ, Dam D, Lee S, Cotman CW (1988) Basic fibroblast growth factor prevents death of lesioned cholinergic neurons in vivo. Nature 332:360-361.

Auer RN, Siesjo BK (1988) Biological differences between ischemia, hypoglycemia, and epilepsy. Ann Neurol 24:699-707.

Baird A, Walicke PA (1989) Fibroblast growth factors. Br Med Bull 45:438-452.

Renveniste H, Drejer J, Schousboe A, Diemer NH (1984) Elevation of the extracellular concentrations of glutamate and aspartate in rat hippocampus during transient cerebral ischemia monitored by intracerebral microdialysis. J Ncurochem 43:1369-1374.

Berg MM, Sternberg DW, Parada LF, Chao MV (1992) K-252a inhibits nerve growth factor-induced trk proto-oncogene tyrosine phosphorylation and kinase activity. J Biol Chem 267:13-16.

Blenis J, Erikson RL (1986) Regulation of protein kinase activities in PC12 pheochromocytoma cells. EMBO J 5:3441-3447.

Bockaert J, Dumuis A, Manzoni O, Nargeot J, Oomagari K, Pin J-P, Rassendren F, Sebben M, Sladeczek F (1990) Intracellular messengers associated with excitatory amino acid (EAA) receptors. In: Excitatory amino acids and neuronal plasticity (Ben-Ari, ed), pp. 79 91. New York: Plenum.

Bottenstein JE, Skaper SD, Varon SS, Sato GH (1980) Selective survival of neurons from chick embryo sensory ganglionic dissociates utilizing serum-free supplemented medium. Exp Cell Res 125:183190.

Boulton TG, Nye SH, Robbins DJ, Ip NY, Radziejewska E, Morgenbesser SD, DePinho RA, Panayotatos N, Cobb MH, Yancopoulos GD (1991) ERKs: a family of protein-serine/threonine kinases that are activated and tyrosine-phosphorylated in response to insulin and NGF. Cell 65:663-675.

Brady MJ, Nairn AC, Wagner JA, Palfrey HC (1990) NGF-induced down-regulation of CaM-dependent protein kinase III in PCl2 cells is mediated by cAMP-dependent protein kinase. $\mathrm{J}$ Neurochem 54 : 1034-1039.

Burstein DE, Blumberg PM, Greene LA (1982) Nerve growth factorinduced neuronal differentiation of $\mathrm{PC} 12$ pheochromocytoma cells: lack of inhibition by a tumor promoter. Brain Res 247:115-119.

Cardell M, Bingren H, Wieloch T, Zivin J, Saitoh T (1990) Protein kinasc $\mathrm{C}$ is translocated to cell membranes during cerebral ischemia. Neurosci Lett 119:228-232.

Cattaneo E, McKay G (1991) Proliferation and differentiation of neuronal stem cells regulated by nerve growth factor. Nature 347:762765 .

Chan BL, Chao MV, Saltiel AR (1989) Nerve growth factor stimulates the hydrolysis of glycosyl-phosphatidylinositol in PC-12 cells: a mechanism of protein kinase C regulation. Proc Natl Acad Sci USA 86: $1756-1760$.

Chao MV (1992) Growth factor signaling: where is the specificity? Cell 68:995-997. 
Choi DW (1990) The role of glutamate neurotoxicity in hypoxicischemic neuronal death. Annu Rev Neurosci 13:171-182.

Cohen JJ, Duke RC (1984) Glucocorticoid activation of a calciumdependent endonuclease in thymocyte nuclei leads to cell death. $J$ Immunol 132:38-42.

Contreras ML, Guroff G (1987) Calcium-dependent nerve growth factor-stimulated hydrolysis of phosphoinositides in PC1 2 cells. J Neurochem 48:1466-1472.

Cremins J, Wagner JA, Halegoua S (1986) Nerve growth factor action is mediated by cyclic AMP- and $\mathrm{Ca}^{2+} /$ phospholipid-dependent protein kinases. J Cell Biol 103:887-893.

Damon DH, D'Amore PA, Wagner JA (1990) NGF and FGF regulate neurite outgrowth and gene expression in PC12 cells via both PKCand cAMP-independent mechanism(s). J Cell Biol 110:1333-1339.

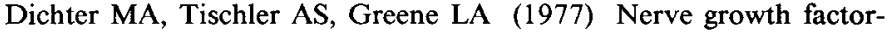
induced increase in electrical excitability and acetylcholine sensitivity of a rat pheochromocytoma cell line. Nature 268:501-504.

Ernsberger U, Sendtner M, Rohrer H (1989) Proliferation and differentiation of embryonic chick sympathetic neurons: effects of ciliary neurotrophic factor. Neuron 2:1275-1284.

Faktorovich EG, Steinberg RH, Yasumura D, Matthes MT, LaVail MM (1992) Basic fibroblast growth factor and local injury protect photoreceptors from light damage in the rat. J Neurosci 12:3554-3567.

Finklestein SP, Apostolides PJ, Caday CG, Prosser J, Philips MF, Klagsbrun M (1988) Increased basic fibroblast growth factor (bFGF) immunoreactivity at the site of focal brain wounds. Brain Res 20:253259.

Finklestein SP, Caday CG, Kano M, Berlove DJ, Hsu CY, Moskowitz M, Klagsbrun M (1990a) Growth factor expression after stroke. Stroke 21 [Suppl III]:III-122-III-124.

Finklestein SP, Fanning PJ, Caday CG, Powell PP, Foster J, Clifford EM, Klagsbrun M (1990b) Increased levels of basic fibroblast growth factor (bFGF) following focal brain injury. Restor Neurol Neurosci 1:387-394

Gage FH, Tuszynski MH, Chen KS, Fagan AM, Higgins GA (1991) Nerve growth factor function in the central nervous system. Curr Top Microbiol Immunol 165:71-93.

Ginty DD, Glowacka D, DeFranco C, Wagner JA (1991) Nerve growth factor-induced neuronal differentiation after dominant repression of both type I and type II c $\Lambda \mathrm{MP}$-dependent protein kinase activity. J Biol Chem 266:15325-15333.

Ginty DD, Fanger GR, Wagner JA, Maue RA (1992) The activity of cAMP-dependent prolein kinase is required at a posttranslational level for induction of voltage-dependent sodium channels by peptide growth factors in PC1 2 cells. J Cell Biol 116:1465-1473.

Gnahn H, Hefti F, Heumann R, Schwab M, Thoenen H (1983) NGFmediated increase of choline acetyltransferase (ChAT) in the neonatal rat forebrain; evidence for a physiological role of NGF in the brain? Dev Brain Res 9:45-52.

Goldberg MP, Weiss JH, Pham P-C, Choi DW (1987) $N$-methylD-aspartate receptors mediate hypoxic neuronal injury in cortical culture. J Pharmacol Exp Ther 243:784-791.

Greenberg ME, Greene LA, Ziff EB (1985) Nerve growth factor and epidermal growth factor induce rapid transient changes in proto-oncogene transcription in PC12 cells. J Biol Chem 260:14101-14110.

Greene LA (1978) Nerve growth factor prevents the death and stimulates the neuronal differentiation of clonal $\mathrm{PC} 12$ pheochromocytoma cells in serum-free medium. J Cell Biol 78:747-755.

Greene LA, Tischler AS (1976) Establishment of a noradrenergic clonal line of rat adrenal pheochromocytoma cells which respond to nerve growth factor. Proc Natl Acad Sci USA 73:2424-2428.

Greene LA, Tischler AS (1982) PC12 pheochromocytoma cultures in neurobiological research. Adv Cell Neurobiol 3:373-414.

Hall FL, Fernyhough P, Ishii DN, Vulliet PR (1988) Suppression of nerve growth factor-directed neurite outgrowth in PC12 cells by sphingosine, an inhibitor of protein kinase C. J Biol Chem 263:44604466.

Hama T, Huang K-P, Guroff G (1986) Protein kinase C as a component of a nerve growth factor-sensitive phosphorylation system in PC12 cells. Proc Natl Acad Sci USA 83:2353-2357.

Hashimoto S (1988) K-252a, a potent protein kinase inhibitor, blocks nerve growth factor-induced neurite outgrowth and changes in the phosphorylation of proteins in PC12h cells. J Cell Biol 107:15311539.

Hashimoto S, Hagino A (1989) Blockage of nerve growth factor action in $\mathrm{PC} 12 \mathrm{~h}$ cells by staurosporine, a potent protein kinase inhibitor. $\mathrm{J}$ Neurochem 53:1675-1685.

Hashimoto S, Hagino A (1990) Nerve growth factor-induced transient increase in the phosphorylation of ribosomal protein S6 mediated through a mechanism independent of cyclic AMP-dependent protein kinase and protein kinase C. J Neurochem 55:970-980.

Heasley LE, Johnson GL (1989) Detection of nerve growth factor and epidermal growth factor-regulated protein kinases in PC12 cells with synthetic peptide substrates. Mol Pharmacol 35:331-338.

Hefti $F$ (1986) Nerve growth factor promotes survival of septal cholinergic neurons after fimbrial transections. J Neurosci 6:2155-2162.

Hefti F, Dravid A, Hartikka J (1984) Chronic intraventricular injections of nerve growth factor elevate hippocampal choline acetyltransferase activity in adult rats with partial septo-hippocampal lesions. Brain Res 293:305-311.

Hidaka H, Inagaki M, Kawamoto S, Sasaki Y (1984) Isoquinolinesulfonamides, novel and potent inhibitors of cyclic nucleotide dependent protein kinase and protein kinase C. Biochemstry 23:50365041.

Huff K, End D, Guroff G (1981) Nerve growth factor-induced alteration in the response of $\mathrm{PC} 12$ pheochromocytoma cells to epidermal growth factor. J Cell Biol 88:189-198.

Johnston MV, Rutkowski JL, Wainer BH, Long JB, Mobley WC (1987) NGF effects on developing forebrain cholinergic neurons are regionally specific. Neurochem Res 12:985-994.

Kalman D, Wong B, Horvai AE, Cline MJ, O'Lague PH (1990) Nerve growth factor acts through cAMP-dependent protein kinase to increase the number of sodium channels in PC12 cells. Neuron 4:355366.

Kinoshita A, Yamada K, Hayakawa T, Kataoka K, Mushiroi T, Kohmura E, Mogami H (1990) Modification of anoxic neuronal injury by human recombinant epidermal growth factor and its possible mechanism. J Neurosci Res 25:324-330.

Kirschenbaum B, Pulsinelli WA (1990) Posthoc phosphorylation of proteins derived from ischemic rat hippocampus, striatum and neocortex. Brain Res 511:21-29.

Klein R, Jing S, Nanduri V, O'Rourke E, Barbacid M (1991) The trk proto-oncogene encodes a receptor for nerve growth factor. Cell 65 : 189-197.

Koizumi S, Contreras ML, Matsuda Y, Hama T, Lazarovici P, Guroff $G$ (1988) K-252a: a specific inhibitor of the action of nerve growth factor on PC12 cells. J Neurosci 8:715-721.

Kondratyev AD, Popova ON, Scvcrin SE, Choladzc MA, Shmyrev II, Tubasheva IA, Zotova EE, Posypanova GA, Severin ES (1990) Nerve growth factor stimulates protein kinase $\mathrm{C}$ translocation in $\mathrm{PC} 12$ cells. FEBS Lett 264:75-77.

Korsching S, Auburger G, Heumann R, Scott J, Thoenen H (1985) Levels of nerve growth factor and its mRNA in the central nervous system of the rat correlate with cholinergic innervation. EMBO J 4:1389-1393

Kromer LF (1987) Nerve growth factor treatment after brain injury prevents neuronal death. Science 235:214-216.

Lipton SA, Wagner JA, Madison RD, D'Amore PA (1988) Acidic fibroblast growth factor enhances regeneration of processes by postnatal mammalian retinal ganglion cells in culture. Proc Natl Acad Sci USA 85:2388-2392.

Logan A, Frautschy SA, Gonzalez A-M, Baird A (1992) A time course for the focal elevation of synthesis of basic fibroblast growth factor and one of its high-affinity receptors (flg) following a localized cortical brain injury. J Neurosci 12:3828-3837.

Louis J-C, Magal E, Yavin E (1988) Protein kinase C alterations in the fetal rat brain after global ischemia. J Biol Chem 263:1928219285.

MacDermott AB, Mayer ML, Westbrook GL, Smith SJ, Barker JL (1986) NMDA-receptor activation increases cytoplasmic calcium concentration in cultured spinal cord neurones. Nature 321:519-522.

Maiese K, Boniece IR, DeMeo D, Wagner JA (in press) Peptide growth factors protect against ischemia by preventing nitric oxide toxicity. $J$ Neurosci, in press.

Mattson MP, Murrain M, Guthrie PB, Kater SB (1989) Fibroblast growth factor and glutamate: opposing roles in the generation and degeneration of hippocampal neuroarchitecture. J Neurosci 9:37283740 .

Mayer ML, MacDermott AB, Westbrook GL, Smith SJ, Barker JL (1987) Agonist- and voltage-gated calcium entry in cultured mouse 
spinal cord neurons under voltage clamp measured using arsenazo III. J Neurosci 7:3230-3244.

Meakin SO, Shooter EM (1991) Tyrosine kinase activity coupled to the high-affinity nerve growth factor-receptor complex. Proc Natl Acad Sci USA 88:5862-5866.

Miyasaka T, Chao MV, Sherline P, Saltiel AR (1990) Nerve growth factor stimulates a protein kinase in PC12 cells that phosphorylates microtubule-associated protein-2. J Biol Chem 265:4730-4735.

Mobley WC, Schenker A, Shooter EM (1976) Characterization and isolation of proteolytically modified nerve growth factor. Biochemistry 15:5543-5551.

Mobley WC, Rutkowski JL, Tennekoon GI, Buchanan K, Johnston MV (1985) Choline acetyltransferase activity in striatum of neonatal rats increased by nerve growth factor. Science 229:284-287.

Morrison RS, Gross JL, Moskal JR (1988a) Inhibition of protein kinase $\mathrm{C}$ activity promotes the neurotrophic action of epidermal and basic fibroblast growth factors. Brain Res 473:141-146.

Morrison RS, Keating RF, Moskal JR (1988b) Basic fibroblast growth factor and epidermal growth factor exert differential trophic effects on CNS neurons. Neurosci Res 21:71-79.

Nakano H, Kobayashi E, Takahashi I, Tamaoki Y, Kuzuu Y, Iba H (1987) Staurosporine inhibits tyrosine-specific protein kinase activity of rous sarcoma virus transforming protein p60. J Antibiot (Tokyo) 40:706-708.

Nixon JS, Wilkinson SE, Davis PD, Sedgwick AD, Wadsworth J, Westmacott D (1991) Modulation of cellular processes by H7, a nonselective inhibitor of protein kinases. Agents Actions 32:188-193.

Ohmichi M, Decker SJ, Pang L, Saltiel AR (1992) Inhibition of the cellular actions of nerve growth factor by staurosporine and $\mathrm{K} 252 \mathrm{~A}$ results from the attenuation of the activity of the Trk tyrosine kinase. Biochemistry 31:4034-4039.

Otto D, Unsicker K (1990) Basic FGF reverses chemical and morphological deficits in the nigrostriatal system of MPTP-treated mice. J Neurosci 10:1912-1920.

Otto D, Unsicker K, Grothe C (1987) Pharmacological effects of nerve growth factor and fibroblast growth factor applied to the transected sciatic nerve on neuron death in adult rat dorsal root ganglia. Neurosci Lett 83:156-160.

Pauwels PJ, van Assouw HP, Leysen JE (1989) Attenuation of neurotoxicity following anoxia or glutamate receptor activation in EGFand hippocampal extract-treated neuronal cultures. Cell Signal 1:4554.

Posypanova GA, Severin SE, Kondratyev AD (1990) Effect of protein kinase modulators on the induction of morphological differentiation of pheochromocytoma $\mathrm{PCl} 2$ cells by nerve and fibroblast growth factors. Biotechnol Appl Biochem 12:20-27.

Rehncrona S, Rosen I, Siesjo BK (1981) Brain lactic acidosis and ischemic cell damage: 1 . Biochemistry and neurophysiology. J Cereb Blood Flow Metab 1:297-311.

Rothman SM, Olney JW (1986) Glutamate and the pathophysiology of hypoxic-ischemic brain damage. Ann Neurol 19:105-111.
Rukenstein A, Rydel RE, Greene LA (1991) Multiple agents rescue PC1 2 cells from serum-free cell death by translation- and transcription-independent mechanisms. J Neurosci 11:2552-2563.

Rydel RE, Greene LA (1988) Cyclic AMP analogues promote survival and neurite outgrowth in cultures of rat sympathetic and sensory neurons independently of nerve growth factor. Proc Natl Acad Sci USA 85:1257-1261.

Saitoh T, Masliah E, Jin L-W, Cole GM, Wieloch T, Shapiro IP (1991) Biology of disease: protein kinases and phosphorylation in neurologic disorders and cell death. Lab Invest 64:596-616.

Schlessinger J, Ullrich A (1992) Growth factor signaling by receptor tyrosine kinases. Neuron 9:383-391.

Shi Y, Sahai BM, Green DR (1989) Cyclosporin A inhibits activationinduced cell death in T-cell hybridomas and thymocytes. Nature 339: $625-626$

Sievers J, Hausmann B, Unsicker K, Berry M (1987) Fibroblast growth factors promote the survival of adult rat retinal ganglion cells after transection of the optic nerve. Neurosci Lett 76:157-162.

Stemple DL, Mahanthappa NK, Anderson DJ (1988) Basic FGF induces neuronal differentiation, cell division, and NGF dependence in chromaffin cells: a sequence of events in sympathetic development. Neuron 1:517-525.

Tamm I, Kikuchi T (1991) Activation of signal transduction pathways protects quiescent Balb/c3T3 fibroblasts against death due to serum deprivation. J Cell Physiol 148:85-95.

Thoenen H, Barde YA (1980) Physiology of nerve growth factor. Physiol Rev 60:1284-1334.

Tischler AS, Ruzicka LA, Perlman RL (1990) Mimicry and inhibition of nerve growth factor effects: interactions of staurosporine, forskolin, and $\mathrm{K} 252 \mathrm{a}$ in $\mathrm{PC} 12$ cells and normal rat chromaffin cells in vitro. $\mathbf{J}$ Neurochem 55:1159-1165.

Volonte C, Rukenstein A, Loeb DM, Greene LA (1989) Differential inhibition of nerve growth factor responses by purine analogues: correlation with inhibition of a nerve growth factor-activated protein kinase. J Cell Biol 109:2395-2403.

Vulliet PR, Hall FL, Mitchell JP, Hardie DG (1989) Identification of a novel proline-directed serine/threonine protein kinase in rat pheochromocytoma. J Biol Chem 264:16292-16298.

Walicke PA (1988) Basic and acidic fibroblast growth factors have trophic effects on neurons from multiple CNS regions. J Neurosci 8:2618-2627.

Westerberg E, Monaghan DH, Kalimo H, Cotman CW, Wieloch TW (1989) Dynamic changes of excitatory amino acid receptors in the rat hippocampus following transient cerebral ischemia. J Neurosci 9:798-805.

Williams LR, Varon S, Peterson GM, Wictorin K, Fischer W, Bjorklund A, Gage FH (1986) Continuous infusion of nerve growth factor prevents basal forebrain neuronal death after fimbria fornix transection. Proc Natl Acad Sci USA 83:9231-9235. 